\title{
How I Treat Acute and Persistent Sickle Cell Pain.
}

Samir K. Ballas

Thomas Jefferson University

Follow this and additional works at: https://jdc.jefferson.edu/cardeza_foundation

Part of the Hematology Commons

Let us know how access to this document benefits you

\section{Recommended Citation}

Ballas, Samir K., "How I Treat Acute and Persistent Sickle Cell Pain." (2020). Cardeza Foundation for Hematologic Research. Paper 59.

https://jdc.jefferson.edu/cardeza_foundation/59

This Article is brought to you for free and open access by the Jefferson Digital Commons. The Jefferson Digital Commons is a service of Thomas Jefferson University's Center for Teaching and Learning (CTL). The Commons is a showcase for Jefferson books and journals, peer-reviewed scholarly publications, unique historical collections from the University archives, and teaching tools. The Jefferson Digital Commons allows researchers and interested readers anywhere in the world to learn about and keep up to date with Jefferson scholarship. This article has been accepted for inclusion in Cardeza Foundation for Hematologic Research by an authorized administrator of the Jefferson Digital Commons. For more information, please contact: JeffersonDigitalCommons@jefferson.edu. 


\section{Mediterranean Journal of Hematology and Infectious Diseases}

\section{$\underline{\text { How I Treat }}$}

\section{How I Treat Acute and Persistent Sickle Cell Pain}

Samir K. Ballas.

Cardeza Foundation for Hematologic Research, Department of Medicine, Sidney Kimmel Medical College, Thomas Jefferson University, Philadelphia, PA, USA.

Competing interests: The authors declare no conflict of Interest.

Abstract. Sickle pain is the hallmark of sickle cell disease (SCD). It could be acute, persistent/relapsing, chronic, or neuropathic. Although there is a general consensus that pain is a major manifestation of SCD, there is a controversy as to the types of pain and their interrelationship between acute, chronic, relapsing, persistent, etc. This report first reviews the general approach to the management of acute vaso-occlusive crisis (VOC) pain, including education, counseling, pharmacotherapy, non-pharmacotherapy, and fluid therapy. This is followed by the presentation of five patients that represent typical issues that are commonly encountered in the management of patients with SCD. These issues are: individualized treatment of pain, bilaterality of pain, use of illicit drugs, tolerance to opioids, opioid-induced hyperalgesia, and withdrawal syndrome. The clinical aspects and management of each of these issues are described. Moreover, such complications as tolerance and withdrawal may persist after discharge and may be mistaken as chronic pain rather than resolving, persistent or relapsing pain.

Keywords: Sickle cell disease; Sickle cell anemia; Pain; Vaso-occlusive crisis.

Citation: Ballas S.K. How I treat acute and persistent sickle cell pain. Mediterr J Hematol Infect Dis 2020, 12(1): e2020064, DOI: http://dx.doi.org/10.4084/MJHID.2020.064

This is an Open Access article distributed under the terms of the Creative Commons Attribution License (https://creativecommons.org/licenses/by-nc/4.0), which permits unrestricted use, distribution, and reproduction in any medium, provided the original work is properly cited.

Correspondence to: Samir K. Ballas MD FACP. Cardeza Foundation, Department of Medicine, Sidney Kimmel Medical College, Thomas Jefferson University, 1020 Locust Street, Philadelphia, PA 19107. Tel: 856745 6380, Fax: 856795 0809. E-Mail: Samir.ballas@jefferson.edu

Introduction. The hallmark of sickle cell disease (SCD) is the recurrent acute painful vaso-occlusive crises (VOCs) and the persistent pain (PP) in between crises in about $50 \%$ of adults and $9 \%$ of children. ${ }^{1-3}$ These types of pain are unique to patients with SCD and punctuate the quality of their life with uncertainty, suffering, poor education, poverty, dysfunctional family life, and dependence on a fragile medical support system. The frequency, severity, location, and duration of both the VOCs and PP vary considerably among patients and longitudinally in the same patient. The reasons for these fluctuations are not well known. ${ }^{4}$ Moreover, most patients present with neither obvious precipitating factors nor objective signs. ${ }^{5-7}$ This state of affairs creates suspicion among some providers about the authenticity of the VOCs and the resulting accusations of maladaptive behavior. ${ }^{8}$

The PP between crises has been labeled as chronic pain by some providers. ${ }^{1}$ By doing so, the uniqueness of sickle cell pain is undermined, and the patients with SCD are lumped with other chronic pain syndromes in the general population. This lumping rendered the PP subject to the rules, regulations, and guidelines for the treatment of chronic pain. ${ }^{9}$ Moreover, since patients with SCD use relatively frequent and large doses of opioids, they have been assumed to be associated with the opioid epidemic. Consequently, patients with SCD and pain became often unfairly undertreated with opioids.

The purpose of this report is to describe patients with SCD who presented with different pain characteristics that were addressed and resolved in a manner based on 
the changing reality of pain among patients over the dimensions of space and time. ${ }^{10}$

\section{Overview of Treatment}

Education and counseling. Educating and counseling patients with SCD is a continuous process that starts when first seen and continues through future follow-ups. I explain the beneficial and harmful effects of prescribed medications, including opioids. Prescriptions are given as needed. Vaccines are administered when required. ${ }^{11}$ Patients, parents, and other family members are instructed on what to expect regarding sickle cell syndromes by making them aware of the signs and symptoms of VOCs, infection, acute chest syndrome (ACS), etc. The adoption of good health habits is reinforced, and the avoidance of situations and factors that could precipitate a VOC is emphasized. ${ }^{5,11}$

This process of education and counseling results in a written consent form and individualized treatment plan with the patient or parents if long-term opioids are indicated. ${ }^{12}$ The agreement lists the patient's rights and responsibilities, and the treatment plan contains the type, amount, and route of administration of the opioid in question, including random drug urine testing.

Pharmacotherapy of Pain. I use nonsteroidal antiinflammatory drugs (NSAIDs), short-acting opioids, and adjuvants to treat acute pain. ${ }^{13,14}$ The use of NSAIDS is limited to patients whose serum creatinine is $\leq 1.0 \mathrm{mg} / \mathrm{dL}$, and they have no proteinuria or albuminuria. The adjuvants include antihistamines, antiemetics, laxatives, antidepressants, and gabapintinoids as needed. I go over the personal side effects of opioids listed in Table 1. The use of opioids by patients with SCD is not as problematic as it is in the general population. A review of data from the Centers for Disease Control and Prevention (CDC) between 1999 and 2013 showed that less than 1\% of deaths among patients with SCD was due to opioid overdose, and this low rate of mortality did not change significantly over the 15 -year data. ${ }^{15}$

Fluid Therapy. I encourage my patients to use water for oral hydration and avoid soft drinks as often as possible. Signs and symptoms of dehydration include dry mouth, tongue, and lips, decreased skin turgor, flat neck veins, and serum creatinine level higher than steady-state values. I do not use normal saline for intravenous hydration but use $5 \% \mathrm{DW}$ or other crystalloids. I monitor the status of hydration by determining daily fluid intake and output, daily weight, and check if edema develops. ${ }^{16-18}$ Overhydration, like over blood transfusion, could be fatal. ${ }^{19-21}$

Beyond Pharmacotherapy. With the help of our social workers, we address the psychosocial factors that pertain to each patient and recommend solutions. We
Table 1. Opioid Risks.

1. Mild/Moderate Side Effects:

- Sedation

- Confusion

- Nausea

- Dizziness

- Constipation

2. Serious Medical Side Effects:

- Gonadal suppression

- Respiratory suppression

- Sleep apnea

- Dental complications

3. Serious Neurological and Behavioral Side Effects:

- Physical dependence

- Withdrawal

- Tolerance

- Hyperalgesia

- Addiction

- Pseudo addiction

- Abuse, misuse, diversion

also recommend nonpharmacologic therapies such as meditation, yoga, massage, relaxation, tai chi, etc..$^{22,23}$

Neuropathophysiology of Pain. This was previously reported $^{10}$ and summarized in Table 2 and Figure 1. ${ }^{24}$

Table 2. Pathways of the Transmission of painful Stimuli.

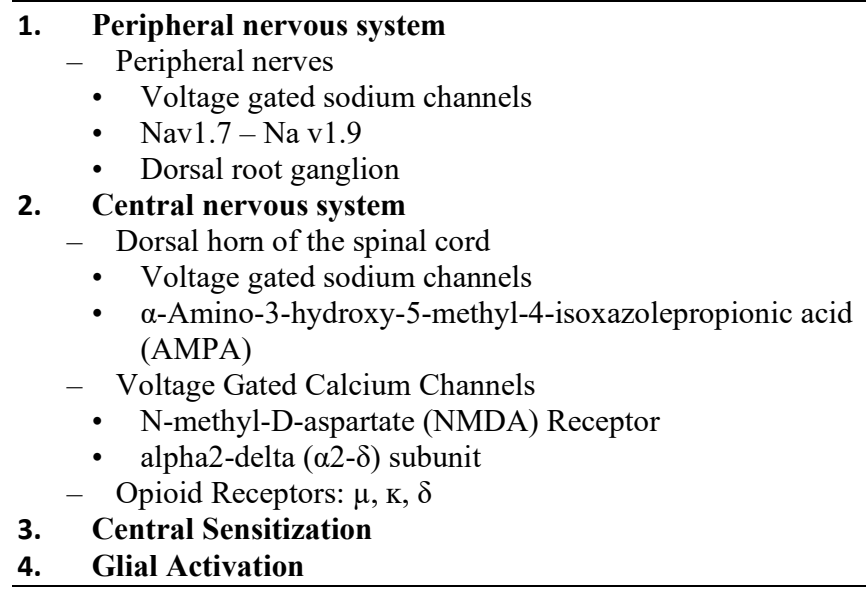

Patient 1: A woman with $\mathrm{Hb}$ SC disease and VOC that went amiss. A 39-year old African American woman known to have hemoglobin $(\mathrm{Hb}) \mathrm{SC}$ disease was admitted to the hospital with the diagnosis of VOC. The pain involved the left shoulder and the upper/lower back and was constant, sharp and throbbing in nature with an intensity score of 10 on a scale from 0 (no pain) to 10 (most severe pain). Past medical history was significant for VOCs at a rate of 2-3 VOCs per year with no pain between VOCs, avascular necrosis (AVN) of the left humeral joint, pneumonia, urinary tract infection, and a remote history of allergy to morphine. In the emergency department (ED), she was given meperidine $125 \mathrm{mg}$ intravenously (IV) every two hours. She did not achieve adequate pain relief after receiving 3 doses of 


\section{Molecular Mechanism of Pain}

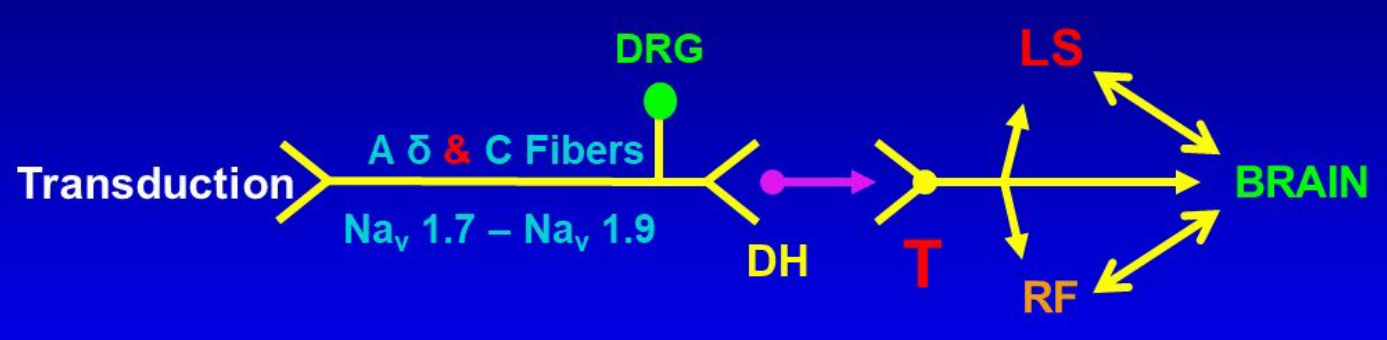

Transmission

Modulation

Perception

Figure 1. Pathways through which pain stimuli are transmitted from the periphery to the brain. Nav1.7 - Nav1.9 are peripheral voltagegated sodium channels; DRG: Dorsal root ganglion; DH: Dorsal horn of the spinal cord; T: Thalamus; RF: Reticular formation; LS: Limbic system. Adapted from Semin Hematol 2001; 38(4):307-314. Used with permission.

meperidine and, hence, was admitted to the hospital. The attending provider decided to start her on patientcontrolled analgesia (PCA) pump using morphine lockout dose $1 \mathrm{mg}$, lockout interval 10 minutes, and a one-hour dose limit of $8 \mathrm{mg}$ morphine. The patient indicated that she is allergic to morphine and usually receives meperidine for pain, but she could not give details about the nature of the allergy to morphine. About 8 hours after starting the PCA, she experienced hallucinations, disorientation, fever $103^{\circ} \mathrm{F}$, chest oppression, and difficulty breathing with pulse Oximetry of $86 \%$. She was transferred to the intensive care unit and intubated. The chest $\mathrm{x}$-ray was normal. She recovered within 24 hours, and management of pain was resumed with meperidine and was discharged 7 days after admission.

Comments on patient 1. Management of patients with sickle cell pain should be individualized. Patients with SCD are authorities on their disease. They know what helps them most. Accordingly, providers should listen, believe, and respect patients unless proven otherwise. The selection of a specific opioid and its dose should be based on the patient's previous experience. No opioid or a specific dose of an opioid applies to all patients all the time. Opioids are ligands that bind to receptors and slow the transmission of painful stimuli along the central nervous system pathways. The binding to and activation of a specific receptor by an opioid vary considerably among patients. Opioid receptors are G protein-coupled with exogenous and endogenous opioids as ligands..$^{25}$ Recent studies ${ }^{25-27}$ have revealed a helical structure of the opioid receptors, which forms pockets in which the corresponding ligand (opioid) fits snugly. Not all opioids fit snugly into the same receptor's pocket. This explains why some patients may have better analgesia with a certain opioid but not with another opioid.

Patient 2: A man with SCA and urine drug screen positive for cannabis and phencyclidine. A 22 yearold-African American man with sickle cell anemia (SCA) whose past medical history was significant for frequent VOCs that required hospitalizations $>5$ times per year with intermittent pain between VOCs. Pain during crises was usually constant, sharp, and throbbing in nature with a score of 8-10/10 and involved the low back, right shoulder, knees, and legs. Complications of his disease included ACS, AVN of hips and right shoulder, priapism, and frequent blood transfusions. In addition, he had asthma as a child and heparin-induced thrombocytopenia. He refused to take hydroxyurea. Social history was positive for tobacco, cannabis, and alcohol use. Lab data in the steady-state included $\mathrm{Hb}$ that varied between 8 and $10 \mathrm{~g} / \mathrm{dL}, \mathrm{Hb} F \quad 11 \%$, reticulocyte count $10-15 \%$, WBC count $8-14 \mathrm{~B} / \mathrm{L}$, normal platelet count, mildly elevated total bilirubin level and normal hepatic and renal parameters. Pain management included morphine and ketorolac during hospitalizations and oxycodone/ acetaminophen (Percocet) as an outpatient. 
When first seen in our center, agreement, and consent forms that included random urine drug testing were discussed and signed by the patient and the provider. The first random urine drug testing done was positive for opiates and cannabinoids. Intensive counseling indicated that he smoked cannabis because Percocet did not give him adequate pain relief. The issue was resolved by replacing Percocet with morphine for the treatment of pain as an outpatient with the patient affirmation that he will discontinue using cannabis subject to confirmation by random urine drug testing. Indeed, random urine drug testing one year later was negative for cannabis and positive for the opiates (morphine) he was taking. Unfortunately, the random urine drug testing done later when he was 24 years old was positive for opiates and phencyclidine.

Another round of counseling revealed that phencyclidine gave him much better pain relief than morphine used to do. Accordingly, pain management was modified to use methadone up to $60 \mathrm{mg}$ orally/day instead of morphine and 5\% lidocaine patches to apply over the most painful area for a maximum of 8 hours per day as needed. Electrocardiogram (EKG) before and after using methadone showed no prolongation of the QTC interval. Methadone was chosen because, like phencyclidine, it inhibits the N-methyl-D-aspartate (NMDA) channel but less severely. This approach resulted in the discontinuation of phencyclidine and repeating urine drug test at the age of 25 years and again at the age of 26 years when he was last seen was positive for opiates only and negative for cannabinoids and phencyclidine.

Comment on patient 2 . This patient is a typical example of opioid tolerance that leads to the use of illicit drugs. It is defined as reduced potency of the analgesic effect of an opioid after repeated administration or the need for higher doses to maintain the same result. It shifts the dose-response curve to the right (Figure 2A). ${ }^{28}$ The binding of an opioid to its receptor generates a series of reactions that could culminate in tolerance, as shown in Figure 3. ${ }^{29}$

Recent studies in mice have shown that tolerance to morphine seems to be modulated by the gutmicrobiome-central nervous system interactions. ${ }^{30-32}$

Management of opioid tolerance entails the use of NMDA inhibitors. Actually, the illicit phencyclidine used by this patient is a potent inhibitor of the NMDA (Figure 4) not only at the level of the spinal cord but in all other tissues and organs and, hence, could be lethal. ${ }^{33}$

The NMDA channel is a complex structure. ${ }^{34}$ It is both a receptor and a calcium-gated channel. ${ }^{35,36}$ Therapeutic inhibitors of NMDR include ketamine, clonidine, Lidocaine, dextromethorphan, nitrous oxide, zinc, and methadone..$^{29,37,38}$ More recently, rosuvastatin, $B$ vitamins, and inhibition of platelet-derived growth factor- $\beta$ (PDGFR- $\beta$ ) have been shown to attenuate or
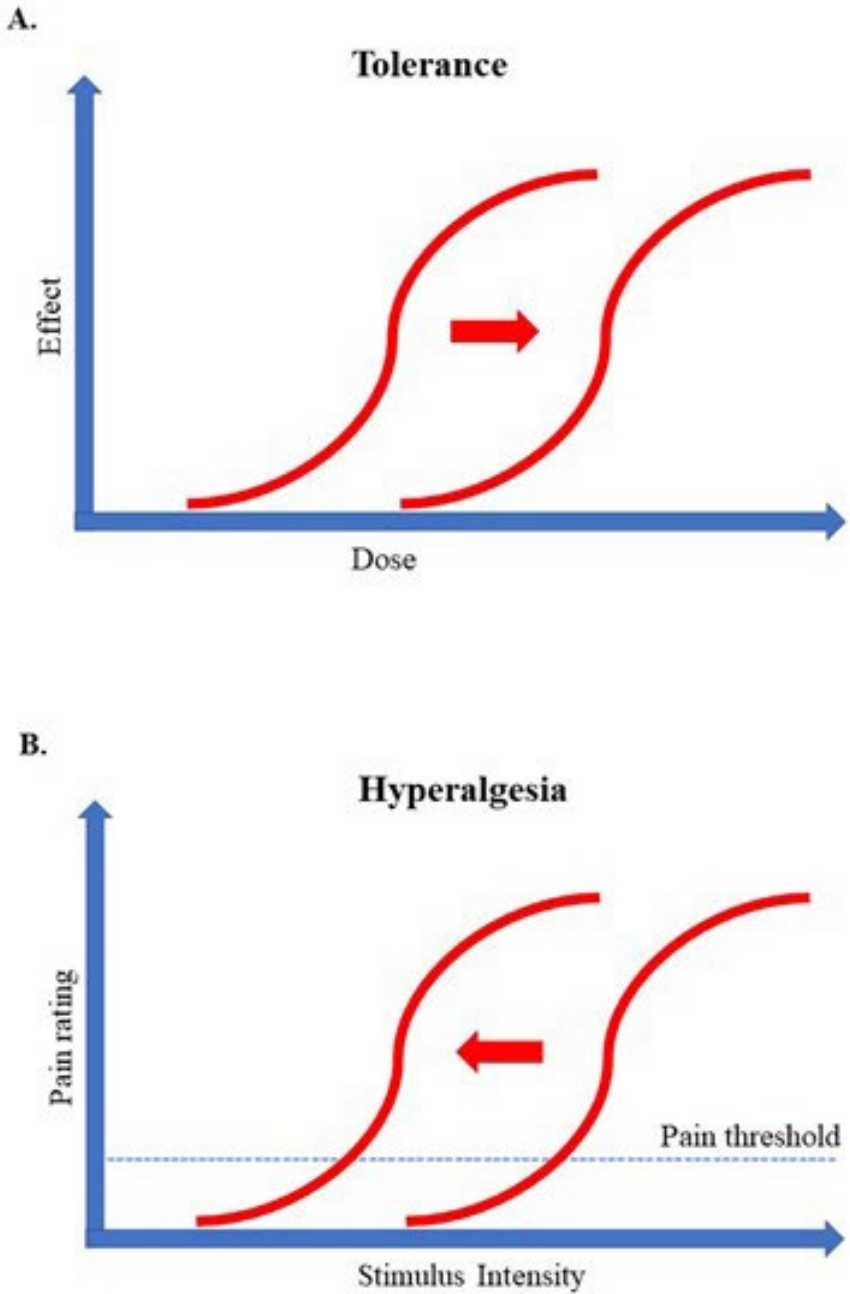

Figure 2. Tolerance and hyperalgesia. Tolerance in A shows a higher dose of an opioid is required to achieve the desired pain relief. Hyperalgesia in B shows that prolonged administration of opioids results in a paradoxical increase in severe pain after minor stimuli. Adapted from Best Pract Res Clin Anaesthesiol 2007; 21:65-83. Used with permission.

eliminate the development of tolerance to morphine in rats and mice. ${ }^{39-42}$ Donica et al. reported that combining imatinib with a previously ineffective dose of morphine led to complete pain relief in male Sprague-Dawley rats. ${ }^{42}$ In addition, imatinib was effective in treating sickle cell VOC in patients with chronic myeloid leukemia and SCA, probably by inhibiting PDGFR$\beta .^{43,44}$

Patient 3: A woman with $\mathrm{Hb} \mathrm{SC}$ and $\mathrm{VOC}$ after Csection that became symmetrically bilateral. A 26year-old pregnant African American woman $\mathrm{Hb}$ SC disease had a Cesarean section (C-section) at week 37 gestation due to signs of fetal distress with abnormal fetal heart tracing. The surgery was uneventful, and the fetus survived with a normal APGAR score. Past medical history was significant for relatively infrequent VOCs $(<2$ per year) and splenic sequestration during infancy that did not require splenectomy. During pregnancy, she took oxycodone $5 \mathrm{mg}$ plus acetaminophen $325 \mathrm{mg}$ (Percocet) prn for pain. The 


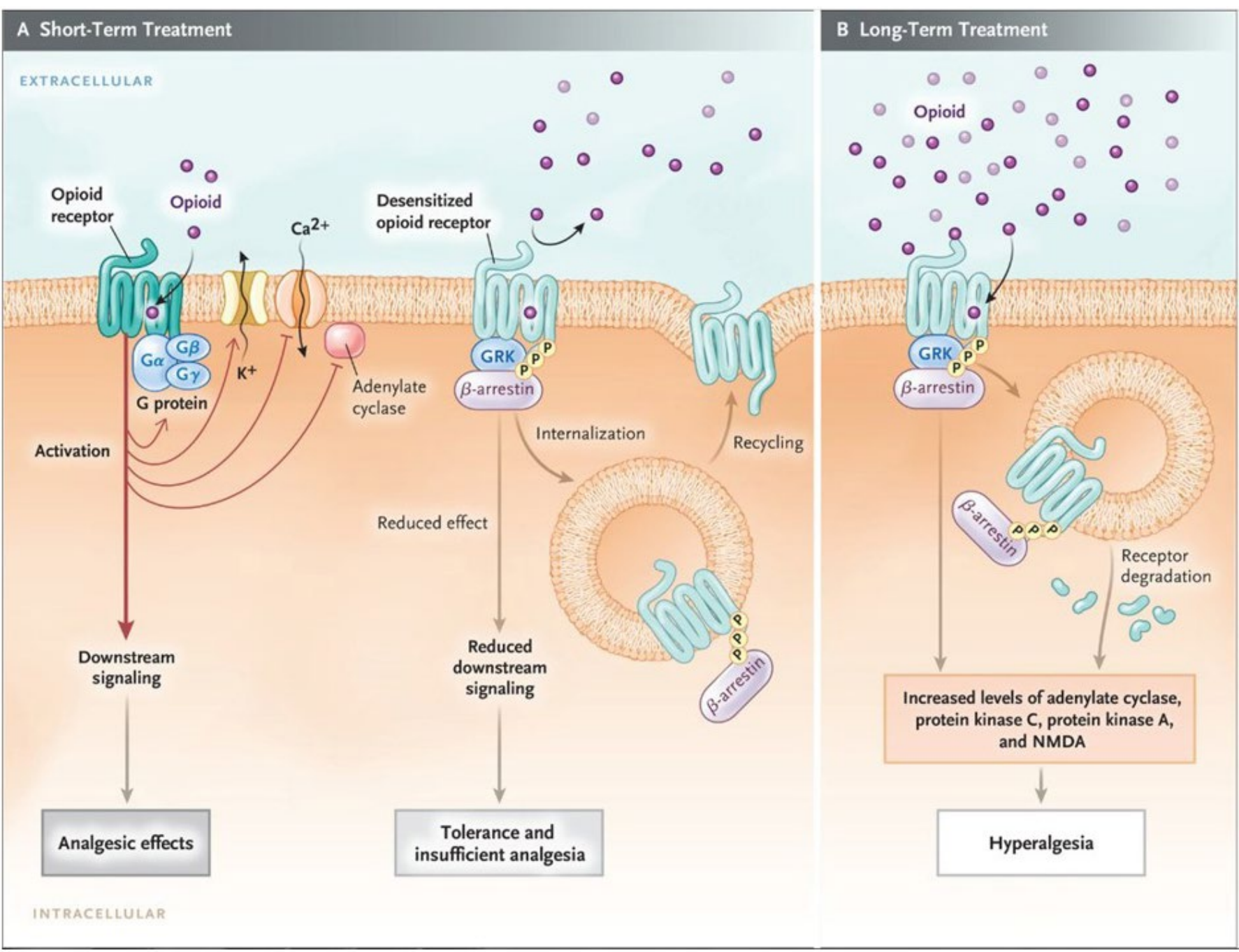

Figure 3. The effect of short- and long-term opioid therapy on opioid-receptor signaling. (A) Binding of an opioid to cell membrane $\mu$-receptors activates the receptor's $\mathrm{G}$ protein that dissociates into $\mathrm{G} \alpha$ and $\mathrm{G} \beta \gamma$ subunits. These, in turn, inhibit voltage-gated calcium channels and activate potassium channels resulting in $\mathrm{K}^{+}$loss causing membrane hyperpolarization and decreased transmission of painful stimuli and opioidanalgesia. However, soon after the opioid binds to its receptor it is subject to phosphorylation by GRK (G-protein-coupled receptor kinase) culminating in the recruitment and binding of $\beta$-arrestin protein to the receptor. This results in desensitization of the receptor thus decreasing the response to the opioid inducing insufficient analgesia and tolerance. (B) Long term therapy with an opioid associated with sustained $\beta$ arrestin binding to the receptor often leads to internalization and degradation of the receptor. This, in turn, initiates a series of reactions that culminate in the activation of the N-methyl-D-aspartate (NMDA) receptor which result in diminishing the analgesic effect, increasing tolerance and opioid-induced-hyperalgesia. From N Engl J Med 2019; 380:365-378. Used with permission.

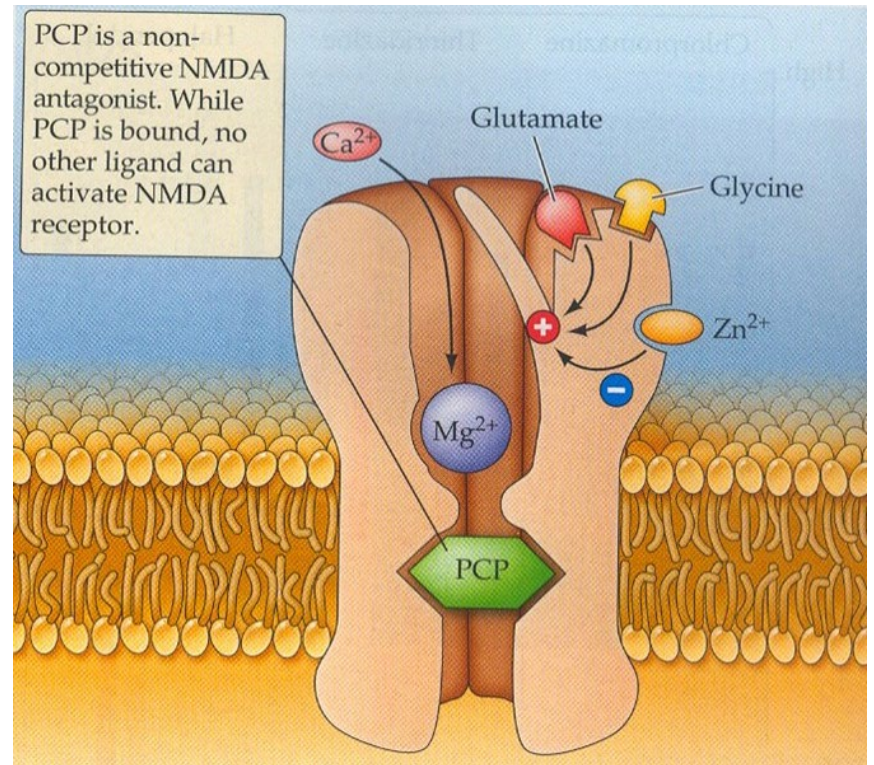

Figure 4. The effect of phencyclidine (PCP) on the N-methyl-Daspartate (NMDA) receptor. PCP acts as a noncompetitive antagonist at NMDA receptor. As long as it is bound it renders the NMDA receptor nonfunctional. From Breedlove S.M., Watson N.V. Behavioral Neuroscience, Eighth Edition. Oxford University Press New York, NY; 2018. Used with permission.

newborn infant had no signs/symptoms of neonatal abstinence syndrome. She was advised not to breastfeed her baby. On the $4^{\text {th }}$ post-operative day, she had a sudden onset of severe pain, swelling, and tenderness in her right ankle. She achieved partial relief with morphine, 6 mg IV every 2 hours. About 24 hours later, she had the same severe "mirror image" pain in her left ankle. Some providers questioned the validity of the symmetrical pain in the left ankle due to the unlikely possibility of having vaso-occlusion in such a symmetrical pattern. Physical exam, however, revealed the presence of 
similar swelling and tenderness over both ankles. Better pain relief was achieved by increasing the dose of morphine to $8 \mathrm{mg}$ IV every 2 hours. She continued to improve gradually and was discharged with her infant ten days after admission.

Comment on patient 3. This patient illustrates two important issues in SCD: postpartum breastfeeding and the pathophysiology of the incidence of symmetrical bilateral pain.

Women with SCD who take opioids during pregnancy must not breastfeed their infants to prevent newborn withdrawal syndrome that could be fatal. Codeine used to be considered a safe opioid analgesic for pain during breastfeeding. This changed after a tragic case report that pertains to an infant who died at the age of 13 days from morphine poisoning; the source of morphine was the codeine that the mother was taking. Further studies showed that the mother was an ultrarapid metabolizer of codeine, due to duplication of the CYP2D6 enzyme that metabolized codeine into morphine. ${ }^{45,46}$ The recommendation changed, indicating that women, in general, must not take opioids during the breastfeeding period.

Symmetrical bilaterality of pain, such as both hips, both knees, was common in more than $60 \%$ of patients enrolled in the PiSCES study ${ }^{47}$ and was also reported by others. ${ }^{48}$ The ankles and feet were the most common locations of bilaterality. The pathophysiology of this bilaterality is not known. One possibility is that it is referred pain to a site different than the original site of pathology. ${ }^{49}$ Shunting of the blood away from the bone marrow, the steal syndrome, is another possibility. ${ }^{48}$ Another explanation of bilaterality is that it is due to central sensitization at the level of the spinal cord, as described by Woolf ${ }^{50}$ in rats. The convergence of nerve fibers from two different sites at the same level in the spinal cord is perceived as pain in both sites (Figure 5). ${ }^{51}$

Most recently, bilaterality seems to be due to a phenomenon called "bioelectric injury mirroring". ${ }^{52}$ This extends our knowledge about the electrophysiology of regenerative response and identifies a novel communication process via a long-range spread of injury signaling (Figure 6). ${ }^{52}$

Patient 4: A woman with $\mathrm{Hb}$ S- $\beta^{0}$-thalassemia whose pain worsened after increasing the dose of morphine. A 29-year-old African American woman with sickle - $\beta^{0}$ thalassemia was admitted to the hospital with VOC involving her low back, chest, and knees. The pain was typical of her VOCs and was constant and sharp/throbbing in nature with an intensity score of $10 / 10$. She also complained of fatigue, malaise, nausea, and vomiting.

Past medical history was significant for frequent VOCs $(\geq 5$ per year) that required treatment in the ED

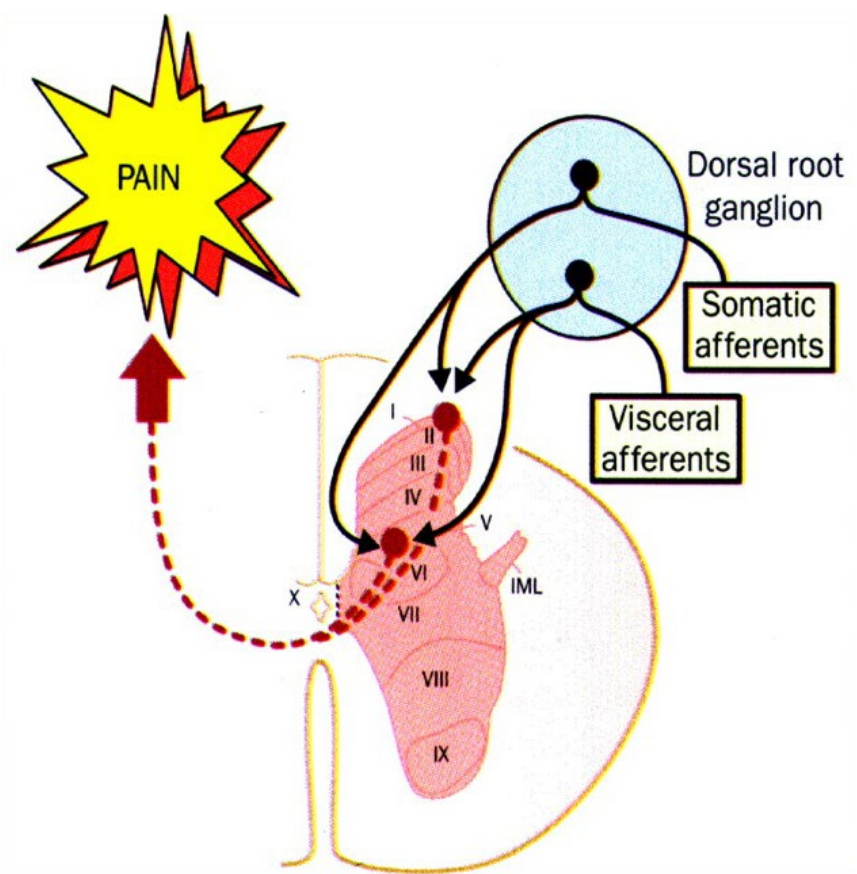

Figure 5. Viscero-somatic convergence of primary afferent fibers on neurons of lamina $I$ and lamina $V$ of the dorsal horn. IML: intermediolateral cell column. From Lancet 1999; 353: 2145-2148. Used with permission.

or in the hospital, cholecystectomy, splenectomy, ACS, repeated blood transfusions, iron overload, deep vein thrombosis, migraine headache, urinary tract infection, and $\mathrm{C}$-section at 34 weeks gestation due to twin pregnancy with both babies in the breech position.

Pain management in this admission included a morphine PCA pump with a basal rate of $4 \mathrm{mg} / \mathrm{h}$ and 1 mg lockout every 10 minutes with a one-hour dose limit of $10 \mathrm{mg}$ and ibuprofen. Emesis was controlled with ondansetron IV. Adjuvants included antihistamines and laxatives. She required two units of RBC transfusion to keep her $\mathrm{Hb}>8 \mathrm{~g} / \mathrm{dL}$. She was also given heparin for deep vein thrombosis prophylaxis. She continued to complain of severe pain that required increasing the dose limit of morphine to $16 \mathrm{mg}$ /hour. At the same time, the distribution and the descriptors of the pain changed; it became worst in her legs and deep burning in nature. Examination showed severe allodynia where a superficial touch of her legs caused severe pain, and she avoided covering her legs with the blanket to prevent pain. The diagnosis of morphine-induces hyperalgesia was made. The dose of morphine was gradually decreased and replaced with an equianalgesic dose of hydromorphone, up to $8 \mathrm{mg}$ iv q2hour. Eventually, adequate relief was achieved with hydromorphone. She was discharged on the $24^{\text {th }}$ hospital day on hydromorphone and ibuprofen.

Comment on patient 4. This patient's pain is a typical example of opioid-induced hyperalgesia $(\mathrm{OIH})$. It is defined as increased sensitivity to pain stimuli (hyperalgesia) and pain caused by ordinarily nonpainful stimuli (referred to as allodynia). Typically, 
A.
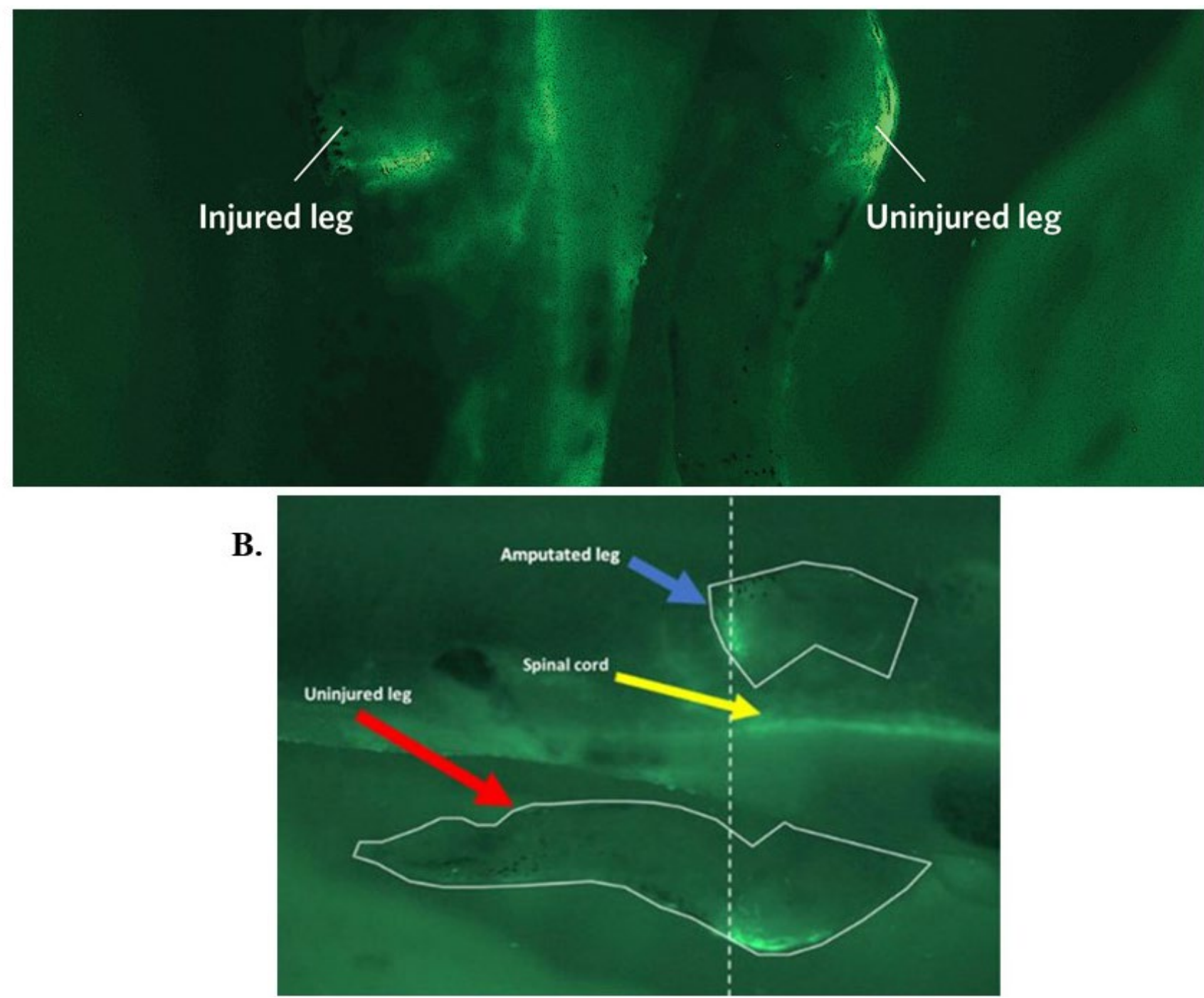

Figure 6. Frogs Have a Bioelectric Mirror. (A) Amputation of one limb triggers a rapid electric response that reflects the injury in the opposite not injured one. From Development 2018; 145: dev164210. (B) Depolarization patterns (brighter green) in the uninjured leg (bottom) occur within seconds of amputation of the opposing leg (top). From Tufts Now. Amputation injury is communicated to opposing limbs. Tufts Now; 2019. Used with permission.

hyperalgesia is noted in parts of the body different from the site of the original pain complaint, and the descriptors of the pain change with some similarity to certain aspects of neuropathic pain such as burning sensation. Unlike tolerance, OIH worsens with higher doses of opioids (Figure 2B). ${ }^{53-55}$

The pathophysiology of OIH is not well understood. A proposed mechanism is the activation of the NMDA receptor. ${ }^{33,53}$ This activation results in calcium influx, which in turn enhances the excitability of neurons, which facilitates further transmission of painful stimuli. $^{33}$

Studies in rats showed that morphine hyperalgesia appears to be secondary to the activation of specific receptors within microglia since the ablation of the microglia prevented OIH. ${ }^{56}$ Figure 7 illustrates how glia interact with neurons and the surrounding blood vessels. ${ }^{57}$

Management of OIH involves weaning from opioids, opioid rotation, and the use of NMDA inhibitors such as methadone, clonidine, Lidocaine, or ketamine as needed Weaning and rotation are usually done together, as was described in this patient.

Patient 5: A man with SCA and recurrent severe pain between VOCs. A 42-year-old African American man with SCA presented to the ED with severe diarrhea and nausea/vomiting of five-days duration. These signs and symptoms were associated with nasal congestion, rhinorrhea, cough, and severe crampy abdominal pain and a VOC with severe pain involving his low back, arms, and legs that brought him to the ED. Medications included Hydroxyurea $1500 \mathrm{mg}$ /day and hydromorphone $4 \mathrm{mg}$ by mouth $\mathrm{q} 2 \mathrm{~h}$ as needed.

Other complications of his SCA included a history of cholecystectomy, obstructive sleep apnea treated at home with oxygen, AVN of the right hip that required arthroplasty, and pneumonia.

Physical exam included a temperature of $99.6^{\circ} \mathrm{F}, \mathrm{RR}$ $30 / \mathrm{min}$ heart rate $130 / \mathrm{min}$, pulse oximetry $99 \%$ on 2 


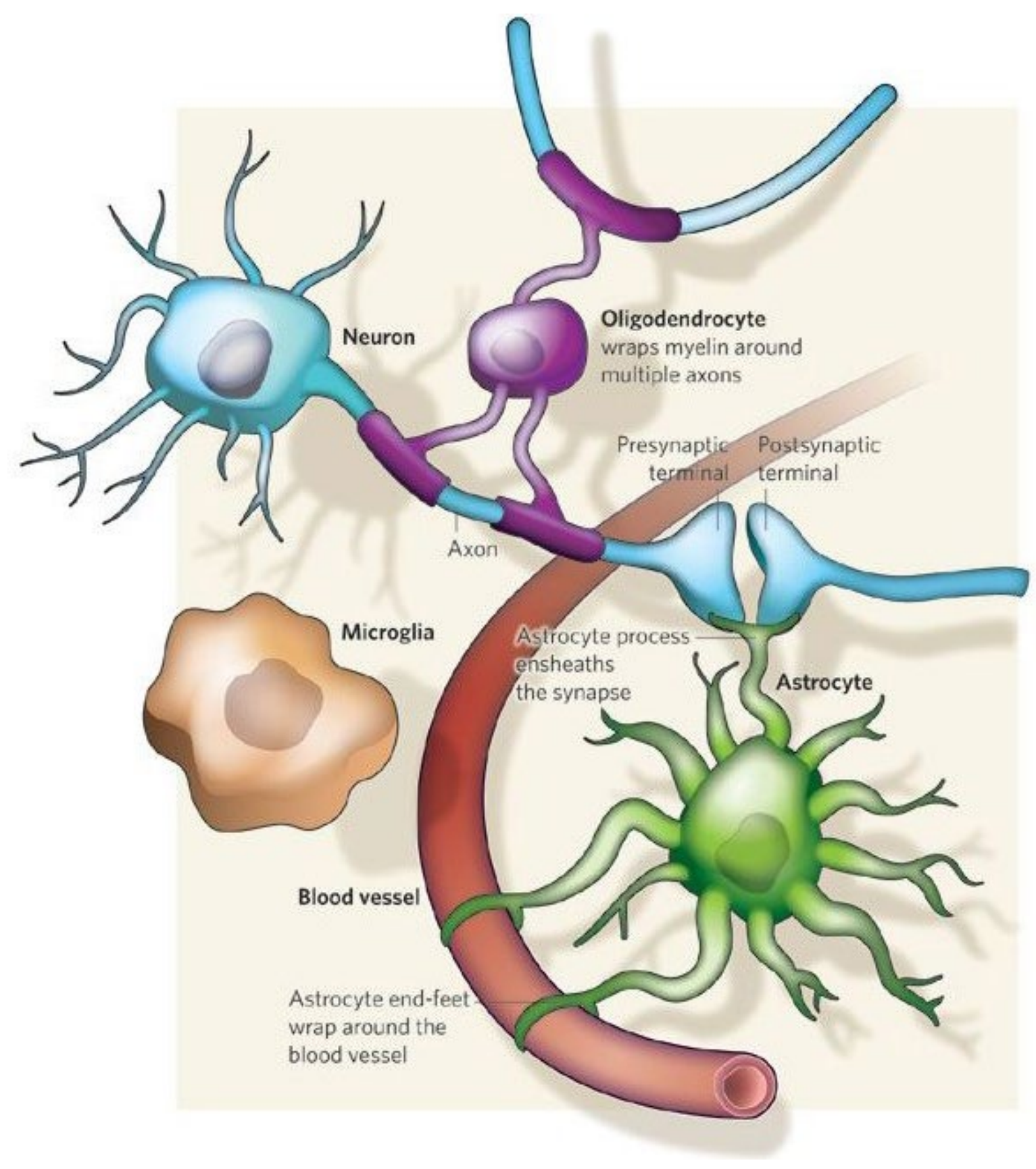

Figure 7. Different types of glia interact with neurons and the surrounding blood vessels. Oligodendrocytes wrap myelin around axons to speed up neuronal transmission. Astrocytes extend processes that ensheath blood vessels and synapses. Microglia keep the brain under surveillance for damage or infection. From Nature 2009; 457: 675-677. Used with permission.

liters oxygen. The patient was restless, anxious, and sweaty. Heart and lung exams were normal. A large ulcer over the left lateral ankle and a smaller ulcer over the right medial ankle were both clean and healing gradually.

Lab data included $\mathrm{Hb} 7.7 \mathrm{~g} / \mathrm{dL}$, reticulocyte count $7.9 \%$, mean corpuscular volume (MCV) $120 \mathrm{fL}$, serum creatinine $1.0 \mathrm{mg} / \mathrm{dL}$ and normal serum electrolytes and liver function tests. A diagnosis of VOC precipitated by viral gastroenteritis was made and treated accordingly. Cultures of stools, urine, and blood were all negative. Chest X-ray and EKG were within normal. Treatment included hydration, opioid analgesia with hydromorphone up-to $8 \mathrm{mg} \mathrm{q} 2 \mathrm{~h}$ IV plus hydroxyzine as an adjuvant, antiemetics with ondansetron, and antilaxatives with loperamide. He improved gradually, and after 15 days of hospitalization, he was discharged on hydromorphone $4 \mathrm{mg}$ by mouth $\mathrm{q} 2 \mathrm{~h}$ and acetaminophen $325 \mathrm{mg} /$ oxycodone $5 \mathrm{mg}$ three times daily as needed.

During the six months after this hospitalization, he was readmitted about once every month with similar signs and symptoms. The diagnosis was changed to gastroenteritis of unknown etiology. The home treatment of pain was changed up to $16 \mathrm{mg}$ hydromorphone po every 2 hours. At this point, he was referred to our center for advice.

A detailed review of the history and the physical exam revealed that the patient had adequate pain relief 
with hydromorphone used at home for 3-4 days. After that, he gradually developed diarrhea, nausea/vomiting, running nose, abdominal cramps, followed by typical symptoms of VOC. This sequence of events recurred before the frequent hospital admissions mentioned above. This sequence of events was typical of withdrawal signs and symptoms, and which was treated with clonidine ( $0.2 \mathrm{mg}$ three times daily) and methadone ( $30 \mathrm{mg}$ daily that was increased gradually to a maximum of $60 \mathrm{mg} /$ day The patient improved gradually and the gastrointestinal and respiratory signs and symptoms resolved. He was advised to continue taking clonidine and methadone for 3-4 weeks, after which he will be reevaluated for possible changes.

Comment on patient 5. Withdrawal syndrome is a conglomerate of physical and behavioral signs and symptoms after the discontinuation or decreasing the dose of an opioid or other addictive drug. The severity of the symptoms depends on the drug in question and its dosage. These include yawning, sweating, lacrimation, rhinorrhea, anxiety, irritability, restlessness, insomnia, dilated pupils, piloerection, chills, tachycardia, hypertension, nausea/vomiting, cramping abdominal pains, diarrhea, and muscle aches and pains.

The incidence and management of withdrawal in SCD have not been well studied. It is often confused with acute or chronic pain, infection, or other comorbidities. It is a cause for hospital readmission within one-two weeks after discharge. ${ }^{58}$

Treatment of severe opioid withdrawal includes methadone plus clonidine either orally $(0.1-0.2 \mathrm{mg}$ every 4-6 hours prn or by using transdermal clonidine patch $0.1 \mathrm{mg}$ daily. Other drugs that may be used to treat withdrawal include buprenorphine plus naloxone orally. ${ }^{59,60}$ Recently, the FDA approved oral lofexidine to treat the symptoms of withdrawal ${ }^{61}$ Lofexidine is a structural analog of clonidine. Clinical trials comparing the two medications showed comparable efficacy, though the severity of adverse events was less than those with clonidine. This decreased risk for adverse effects could potentially make lofexidine a safer option for detoxification. ${ }^{62-64}$

Persistent Sickle Cell Pain. The word "chronic" in SCD is problematic and subject to different explanations. Thus, SCD itself is a chronic disease that is usually symptomatic from childhood through adulthood.

Table 3. Emergency Room Data for Patient $1-5$.

\begin{tabular}{|c|c|c|c|c|}
\hline Patient & Crisis Day & Pain Site Location & Pain Score & Hospital Admission \\
\hline \multirow{4}{*}{ Patient 1} & 1 & Chest & 10 & Yes \\
\hline & 33 & $\begin{array}{l}\text { Right Thigh } \\
\text { Right Knee } \\
\text { Right Leg }\end{array}$ & 10 & No \\
\hline & 75 & $\begin{array}{c}\text { Upper Arms } \\
\text { Elbows } \\
\text { Forearms } \\
\text { Wrists } \\
\text { Hands } \\
\text { Fingers } \\
\end{array}$ & 10 & No \\
\hline & 114 & $\begin{array}{c}\text { Lower Back } \\
\text { Hip }\end{array}$ & 10 & No \\
\hline \multirow{3}{*}{ Patient 2} & 1 & $\begin{array}{c}\text { Left Side } \\
\text { Chest }\end{array}$ & 10 & No \\
\hline & 50 & $\begin{array}{c}\text { Thighs } \\
\text { Legs } \\
\text { Upper Back } \\
\text { Lower Back } \\
\text { Neck } \\
\end{array}$ & 10 & No \\
\hline & 76 & Right Shoulder & 10 & No \\
\hline \multirow{3}{*}{ Patient 3} & 1 & Chest & 9 & No \\
\hline & 37 & Right Foot & 8.5 & No \\
\hline & 76 & Abdomen & 8.0 & No \\
\hline \multirow{3}{*}{ Patient 4} & 1 & Chest & Not Given & Yes \\
\hline & 60 & Legs & Not Given & Yes \\
\hline & 87 & Abdomen & Not Given & Yes \\
\hline \multirow{3}{*}{ Patient 5} & 1 & Knees & 7 & No \\
\hline & 33 & Lower Back & 8 & No \\
\hline & 54 & $\begin{array}{c}\text { Arms } \\
\text { Forearms } \\
\text { Shoulders }\end{array}$ & Not Given & Yes \\
\hline
\end{tabular}


Typically, SCD pain is either acute, which is the hallmark of the disease or chronic. The latter includes such complications as leg ulcers, AVN of humeral or femoral heads, and bone infarcts. ${ }^{65-67}$

These chronic pain syndromes are localized and last for months or years. Recently chronic pain in SCD has been defined as ongoing pain that is present in at least $50 \%$ of days over 3 or 6 months in a single or multiple locations. ${ }^{6,68}$ The problem with this definition is that during the period of 3- or 6-months, patients with SCD may have been treated for acute pain in the ED or hospital, thus confounding this definition. Another definition of chronic pain that was initially introduced by surgeons is acute pain that becomes chronic. This definition applies well to post-operative pain that is acute after surgery but, in some patients, continues in the same operative field for months or years. ${ }^{69}$

Actually, this definition applies to the chronic complications of SCD. Thus, AVN of the hips may start acutely but persists for months or years in the same location. A new definition of chronic pain in SCD is the pain that persists or occurs between VOCs, the so-called chronic on acute pain. ${ }^{70}$ Although this may occur in disorders other than SCD, it is not typical of SCD because the sickle pain between VOCs is not the same: it varies in location, severity, and outcome, as shown in Table 3. Other patients with chronic pain syndromes such as fibromyalgia, osteoarthritis, rheumatoid arthritis, low back pain, migraine, etc. are rarely treated in the ED and rarely require hospital admissions. Sickle cell

\section{References:}

1. Smith WR, Penberthy LT, Bovbjerg VE, McClish DK, Roberts JD, Dahman B, et al. Daily assessment of pain in adults with sickle cell disease. Ann Intern Med. 2008;148(2):94-101. https://doi.org/10.7326/0003-4819-148-2-200801150-00004 PMid:18195334

2. Dampier C, Ely B, Brodecki D, O'Neal P. Characteristics of pain managed at home in children and adolescents with sickle cell disease by using diary self-reports. J Pain. 2002;3(6):461-70. https://doi.org/10.1054/jpai.2002.128064 PMid:14622732

3. Ballas SK, Bauserman RL, McCarthy WF, Castro OL, Smith WR Waclawiw MA. Hydroxyurea and acute painful crises in sickle cell anemia: effects on hospital length of stay and opioid utilization during hospitalization, outpatient acute care contacts, and at home. J Pain Symptom Manage. 2010;40(6):870-82 .

https://doi.org/10.1016/j.jpainsymman.2010.03.020 PMid:20864308 PMCid:PMC3005988

4. Ballas SK. Sickle Cell Pain, 2nd Edition. Washington DC: International Association for the Study of Pain; 2014.

5. Ballas SK, Gupta K, Adams-Graves P. Sickle cell pain: a critical reappraisal. Blood. 2012;120(18):3647-56. https://doi.org/10.1182/blood-2012-04-383430 PMid:22923496

6. Yawn BP, Buchanan GR, Afenyi-Annan AN, Ballas SK, Hassell KL James AH, et al. Management of sickle cell disease: summary of the 2014 evidence-based report by expert panel members. JAMA. 2014;312(10):1033-48.

https://doi.org/10.1001/jama.2014.10517 PMid:25203083

7. Ballas SK, Smith ED. Red blood cell changes during the evolution of the sickle cell painful crisis. Blood. 1992;79(8):2154-63. https://doi.org/10.1182/blood.V79.8.2154.2154 disease and sickle cell pain are unique and should be considered as such.

Patients discharged from the hospital after treatment of uncomplicated VOCs may have:

1. No pain.

2. Resolving mild pain as the VOC continues to resolve gradually.

3. Persistent pain after discharge that requires continued therapy with oral analgesics, (due to tolerance, OIH or withdrawal).

4. Relapsing pain that occurs after a period with no pain (new mild VOC)

I consider the pain that occurs between VOCs is most likely due to tolerance to opioids, withdrawal syndrome, $\mathrm{OIH}$, resolving, or acute relapsing pain. These are specific diagnoses that have specific recommended treatments rather than treating them as chronic pain. Accordingly, it seems the use of Buprenorphine/Naloxone is potentially a good candidate to treat these syndromes as recently reported by Osunkwo et al. ${ }^{71}$

Summary. The acute painful VOC is a unique and hallmark clinical entity of SCD. Recurrent VOCs are not identical but usually vary considerably among patients and longitudinally in the same patient. This is unlike chronic pain that tends to be essentially the same from time to time. The pain between VOCs could be due to tolerance, $\mathrm{OIH}$, withdrawal, resolving, or relapsing VOC.
8. Pentin PL. Drug seeking or pain crisis? Responsible prescribing of opioids in the emergency department. Virtual Mentor. 2013;15(5):410-5. https://doi.org/10.1001/virtualmentor.2013.15.5.ecas2-1305 PMid:23680561

9. Dowell D, Haegerich TM, Chou R. CDC Guideline for Prescribing Opioids for Chronic Pain - United States, 2016. MMWR Recomm Rep. 2016;65(1):1-49.

https://doi.org/10.15585/mmwr.rr6501e1 PMid:26987082

10. Ballas SK. Pathophysiology and principles of management of the many faces of the acute vaso-occlusive crisis in patients with sickle cell disease. Eur J Haematol. 2015;95(2):113-23.

https://doi.org/10.1111/ejh.12460 PMid:25288149

11. Ballas SK. More definitions in sickle cell disease: steady state v base line data. Am J Hematol. 2012;87(3):338. https://doi.org/10.1002/ajh.22259 PMid:22190068

12. Expert Panel Report. Evidence-Based Management of Sickle Cell Disease Bethesda MD: National Heart, Lung, and Blood Institute; 2014 [Available from: $\quad$ http://www.nhlbi.nih.gov/health-pro/guidelines/sickle-celldisease-guidelines/]

13. Ballas SK. Pain management of sickle cell disease. Hematol Oncol Clin North Am. 2005;19(5):785-802. https://doi.org/10.1016/j.hoc.2005.07.008 PMid:16214644

14. Ballas SK. Update on pain management in sickle cell disease Hemoglobin. 2011;35(5):520-9. https://doi.org/10.3109/03630269.2011.610478 PMid:21910604

15. Ruta NS, Ballas SK. The Opioid Drug Epidemic and Sickle Cell Disease: Guilt by Association. Pain Med. 2016;17(10):1793-8. https://doi.org/10.1093/pm/pnw074 


\section{PMid:27152018}

16. Carden MA, Fay M, Sakurai Y, McFarland B, Blanche S, DiPrete C, et al Normal saline is associated with increased sickle red cell stiffness and prolonged transit times in a microfluidic model of the capillary system. Microcirculation. 2017;24(5). https://doi.org/10.1111/micc. 12353 PMid:28106307

17. Carden MA, Fay ME, Lu X, Mannino RG, Sakurai Y, Ciciliano JC, et al Extracellular fluid tonicity impacts sickle red blood cell deformability and adhesion. Blood. 2017;130(24):2654-63. https://doi.org/10.1182/blood-2017-04-780635 PMid:28978568 PMCid:PMC5731085

18. Ballas SK. Of pools, oceans, and the Dead Sea. Blood. 2017;130(24):2578-9

https://doi.org/10.1182/blood-2017-10-811091 PMid:29242205

19. Gardner JW. Death by water intoxication. Mil Med. 2002;167(5):432-4. https://doi.org/10.1093/milmed/167.5.432 PMid:12053855

20. Gutmann FD, Gardner JW. Fatal water intoxication of an Army trainee during urine drug testing. Mil Med. 2002;167(5):435-7.

https://doi.org/10.1093/milmed/167.5.435

21. Serjeant G. Blood transfusion in sickle cell disease: a cautionary tale Lancet. 2003;361(9369):1659-60. https://doi.org/10.1016/S0140-6736(03)13293-X

22. Ballas SK. Self-management of sickle cell disease: a new frontier. J Nat Med Assoc. 2010;102(11):1042-3 https://doi.org/10.1016/S0027-9684(15)30722-7

23. Tanabe P, Porter J, Creary M, Kirkwood E, Miller S, Ahmed-Williams E, et al. A qualitative analysis of best self-management practices: sickle cell disease. J Natl Med Assoc. 2010;102(11):1033-41. https://doi.org/10.1016/S0027-9684(15)30730-6

24. Ballas SK. Sickle cell disease: current clinical management. Semin Hematol. 2001;38(4):307-14. https://doi.org/10.1016/S0037-1963(01)90024-1

25. Waldhoer M, Bartlett SE, Whistler JL. Opioid receptors. Annu Rev Biochem. 2004;73:953-90. https://doi.org/10.1146/annurev.biochem.73.011303.073940 PMid:15189164

26. Manglik A, Kruse AC, Kobilka TS, Thian FS, Mathiesen JM, Sunahara $\mathrm{RK}$, et al. Crystal structure of the micro-opioid receptor bound to a morphinan antagonist. Nature. 2012;485(7398):321-6. https://doi.org/10.1038/nature10954 PMid:22437502 PMCid:PMC3523197

27. Cox BM. Recent developments in the study of opioid receptors. Mol Pharmacol. 2013;83:723-8.

https://doi.org/10.1124/mol.112.083279 PMid:23249538

28. Koppert W, Schmelz M. The impact of opioid-induced hyperalgesia for post-operative pain. Best Pract Res Clin Anaesthesiol. 2007;21(1):65-83. https://doi.org/10.1016/i.bpa.2006.12.004 PMid: 17489220

29. Martyn JAJ, Mao J, Bittner EA. Opioid Tolerance in Critical Illness. N Engl J Med. 2019;380(4):365-78. https://doi.org/10.1056/NEJMra1800222 PMid:30673555 PMCid:PMC6897318

30. Kang M, Mischel RA, Bhave S, Komla E, Cho A, Huang C, et al. The effect of gut microbiome on tolerance to morphine mediated antinociception in mice. Sci Rep. 2017;7:42658.

https://doi.org/10.1038/srep42658 PMid:28211545 PMCid:PMC5314392

31. Akbarali HI, Dewey WL. The gut-brain interaction in opioid tolerance Curr Opin Pharmacol. 2017;37:126-30. https://doi.org/10.1016/j.coph.2017.10.012 PMid:29145012 PMCid:PMC5725258

32. Mischel RA, Dewey WL, Akbarali HI. Tolerance to Morphine-Induced Inhibition of TTX-R Sodium Channels in Dorsal Root Ganglia Neurons Is Modulated by Gut-Derived Mediators. iScience. 2018;2:193-209. https://doi.org/10.1016/i.isci.2018.03.003 PMid:29888757 PMCid:PMC5993194

33. Breedlove S.M., Watson N.V. Behavioral Neuroscience, Eighth Edition. Oxford University Press New York, NY; 2018.

34. CNS Forum. NMDA Receptor. CNS Forum 2002.

35. de Vos JW, Ufkes JG, Kaplan CD, Tursch M, Krause JK, van Wilgenburg $\mathrm{H}$, et al. L-Methadone and D,L-methadone in methadone maintenance treatment: a comparison of therapeutic effectiveness and plasma concentrations. Eur Addict Res. 1998;4(3):134-41. https://doi.org/10.1159/000018936
PMid:9742275

36. Wedekind D, Jacobs S, Karg I, Luedecke C, Schneider U, Cimander K, et al. Psychiatric comorbidity and additional abuse of drugs in maintenance treatment with L- and D,L-methadone. World J Biol Psychiatry. 2010;11(2 Pt 2):390-9. https://doi.org/10.3109/15622970802176487 PMid:20218800

37. Zhang Y, Tao GJ, Hu L, Qu J, Han Y, Zhang G, et al. Lidocaine alleviates morphine tolerance via AMPK-SOCS3-dependent neuroinflammation suppression in the spinal cord. J Neuroinflammation. 2017;14(1):211. https://doi.org/10.1186/s12974-017-0983-6

PMid:29096659 PMCid:PMC5667445

38. Swe KM, Abas AB, Bhardwaj A, Barua A, Nair NS. Zinc supplements for treating thalassaemia and sickle cell disease. Cochrane Database Syst Rev. 2013;6:CD009415. https://doi.org/10.1002/14651858.CD009415.pub2 PMid:23807756

39. Li Y, Shu Y, Ji Q, Liu J, He X, Li W. Attenuation of morphine analgesic tolerance by rosuvastatin in naive and morphine tolerance rats. Inflammation. 2015;38(1):134-41 https://doi.org/10.1007/s10753-014-0015-y PMid:25261133

40. Deng XT, Han Y, Liu WT, Song XJ. B Vitamins Potentiate Acute Morphine Antinociception and Attenuate the Development of Tolerance to Chronic Morphine in Mice. Pain Med. 2017;18(10):1961-74. https://doi.org/10.1093/pm/pnw358 PMid:28379583

41. Wang Y, Barker K, Shi S, Diaz M, Mo B, Gutstein HB. Blockade of PDGFR-beta activation eliminates morphine analgesic tolerance. Nat Med. 2012;18(3):385-7. https://doi.org/10.1038/nm.2633 PMid:22344297 PMCid:PMC3296828

42. Donica CL, Cui Y, Shi S, Gutstein HB. Platelet-derived growth factor receptor-beta antagonism restores morphine analgesic potency against neuropathic pain. PLoS One. 2014;9(5):e97105. https://doi.org/10.1371/journal.pone.0097105 PMid:24820332 PMCid:PMC4018247

43. Stankovic Stojanovic K, Thioliere B, Garandeau E, Lecomte I, Bachmeyer C, Lionnet F. Chronic myeloid leukaemia and sickle cell disease: could imatinib prevent vaso-occlusive crisis? Br J Haematol. $2011 ; 155(2): 271-2$

https://doi.org/10.1111/j.1365-2141.2011.08670.x PMid:21488859

44. Murphy M, Close J, Lottenberg R, Rajasekhar A. Effectiveness of imatinib therapy for sickle cell anemia and chronic myeloid leukemia. Am J Med Sci. 2014;347(3):254-5.

https://doi.org/10.1097/MAJ.0000000000000228 PMid:24553361

45. Koren G, Cairns J, Chitayat D, Gaedigk A, Leeder SJ. Pharmacogenetics of morphine poisoning in a breastfed neonate of a codeine-prescribed mother. Lancet. 2006;368(9536):704. https://doi.org/10.1016/S0140-6736(06)69255-6

46. Sajantila A. Editors' pick: codeine toxicity prediction in young infants genotype the mothers. Investig Genet. 2012;3(1):24.

https://doi.org/10.1186/2041-2223-3-24 PMid:23186321 PMCid:PMC3528413

47. McClish DK, Smith WR, Dahman BA, Levenson JL, Roberts JD, Penberthy LT, et al. Pain site frequency and location in sickle cell disease: the PiSCES project. Pain. 2009;145(1-2):246-51.

https://doi.org/10.1016/j.pain.2009.06.029 PMid:19631468 PMCid:PMC2771372

48. Serjeant GR, Chalmers RM. Current concerns in haematology. 1. Is the painful crisis of sickle cell disease a "steal" syndrome? J Clin Pathol. 1990;43(10):789-91.

https://doi.org/10.1136/jcp.43.10.789 PMid:1699977 PMCid:PMC502823

49. Rathmell J.P., Fields HL. Pain: pathophysiology and management. In: Longo DL, Fauci AS, Kasey S, Hauser R, Jameson LS, Loscaizo JL, editors. Harrison's Principles of Internal Medicine. New York, NY: McGraw Hill; 2012. p. 93-101.

50. Woolf CJ. Evidence for a central component of post-injury pain hypersensitivity. Nature. 1983;306(5944):686-8. https://doi.org/10.1038/306686a0 PMid:6656869

51. Cervero F, Laird JM. Visceral pain. Lancet. 1999;353(9170):2145-8. https://doi.org/10.1016/S0140-6736(99)01306-9 
52. Busse SM, McMillen PT, Levin M. Cross-limb communication during Xenopus hindlimb regenerative response: non-local bioelectric injury signals. Development. 2018;145(19). https://doi.org/10.1242/dev.164210 PMid:30126906

53. Youssef F, Pater A, Shehata M. Opioid-induced Hyperalgesia. J Pain Relief. 2015;4:183-5.

54. Benjamin LJ, Payne R. Pain in sickle cell disease: a multidimensional construct. In: Pace B, editor. Renaissance of Sickle Cell Disease Research in the Genomic Era. London: Imperial College Press; 2007. p. 99-118. https://doi.org/10.1142/9781860947964 0007

55. de Montalembert M, Ferster A, Colombatti R, Rees DC, Gulbis B ENERCA clinical recommendations for disease management and prevention of complications of sickle cell disease in children. Am J Hematol. 2011;86(1):72-5. https://doi.org/10.1002/ajh.21865 PMid:20981677

56. Ferrini F, Trang T, Mattioli TA, Laffray S, Del'guidice T, Lorenzo LE, et al. Morphine hyperalgesia gated through microglia-mediated disruption of neuronal Cl(-) homeostasis. Nat Neurosci. 2013;16:183-92. https://doi.org/10.1038/nn.3295 PMid:23292683 PMCid:PMC4974077

57. Allen NJ, Barres BA. Neuroscience: Glia - more than just brain glue. Nature. 2009;457(7230):675-7. https://doi.org/10.1038/457675a PMid:19194443

58. Ballas SK, Lusardi M. Hospital readmission for adult acute sickle cell painful episodes: frequency, etiology, and prognostic significance. Am J Hematol. 2005;79(1):17-25. https://doi.org/10.1002/ajh.20336 PMid:15849770

59. Burma NE, Kwok CH, Trang T. Therapies and mechanisms of opioid withdrawal. Pain Manag. 2017;7(6):455-9. https://doi.org/10.2217/pmt-2017-0028 PMid:29125396

60. Kenna GA, Nielsen DM, Mello P, Schiesl A, Swift RM. Pharmacotherapy of dual substance abuse and dependence. CNS Drugs. 2007;21(3):213-37. https://doi.org/10.2165/00023210-200721030-00003 PMid:17338593

61. NIDA. FDA approves first medication to reduce opioid withdrawal symptoms National Institute on Drug Abuse website2018 [Available from: https://www.drugabuse.gov/news-events/newsreleases/2018/05/fda-approves-first-medication-to-reduce-opioidwithdrawal-symptoms].

62. Gish EC, Miller JL, Honey BL, Johnson PN. Lofexidine, an \{alpha\}2receptor agonist for opioid detoxification. Ann Pharmacother. 2010;44(2):343-51

https://doi.org/10.1345/aph.1M347 PMid:20040696
63. Gorodetzky CW, Walsh SL, Martin PR, Saxon AJ, Gullo KL, Biswas K. A phase III, randomized, multi-center, double blind, placebo controlled study of safety and efficacy of lofexidine for relief of symptoms in individuals undergoing inpatient opioid withdrawal. Drug Alcohol Depend. 2017;176:79-88. https://doi.org/10.1016/j.drugalcdep.2017.02.020 PMid:28527421

64. Law FD, Diaper AM, Melichar JK, Coulton S, Nutt DJ, Myles JS. Buprenorphine/naloxone versus methadone and lofexidine in community stabilisation and detoxification: A randomised controlled trial of low dose short-term opiate-dependent individuals. J Psychopharmacol. 2017;31(8):1046-55.

https://doi.org/10.1177/0269881117711710

PMid:28631527

65. Ballas SK, Talacki CA, Rao VM, Steiner RM. The prevalence of avascular necrosis in sickle cell anemia: correlation with alphathalassemia. Hemoglobin. 1989;13(7-8):649-55. https://doi.org/10.3109/03630268908998842 PMid:2634666

66. Milner PF, Kraus AP, Sebes JI, Sleeper LA, Dukes KA, Embury SH, et al. Sickle cell disease as a cause of osteonecrosis of the femoral head. N Engl J Med. 1991;325(21):1476-81. https://doi.org/10.1056/NEJM199111213252104 PMid:1944426

67. Minniti CP, Eckman J, Sebastiani P, Steinberg MH, Ballas SK. Leg ulcers in sickle cell disease. Am J Hematol. 2010;85(10):831-3.

https://doi.org/10.1002/ajh.21838 PMid:20872960 PMCid:PMC2953786

68. Dampier C, Palermo TM, Darbari DS, Hassell K, Smith W, Zempsky W. AAPT Diagnostic Criteria for Chronic Sickle Cell Disease Pain. J Pain. 2017;18(5):490-8.

https://doi.org/10.1016/j.jpain.2016.12.016

PMid:28065813

69. Chapman CR, Vierck CJ. The Transition of Acute Postoperative Pain to Chronic Pain: An Integrative Overview of Research on Mechanisms. J Pain. 2017;18(4):359.e1-.e38.

https://doi.org/10.1016/i.jpain.2016.11.004 PMid:27908839

70. Kent ML, Tighe PJ, Belfer I, Brennan TJ, Bruehl S, Brummett CM, et al. The ACTTION-APS-AAPM Pain Taxonomy (AAAPT) Multidimensional Approach to Classifying Acute Pain Conditions. J Pain. 2017;18(5):479-89. https://doi.org/10.1016/j.jpain.2017.02.421 PMid:28495013 PMCid:PMC7323793

71. Osunkwo I, Veeramreddy P, Arnall J, Crawford R, Symanowski JT, Olaosebikan R, et al. Use of Buprenorphine/Naloxone in Ameliorating Acute Care Utilization and Chronic Opioid Use in Adults with Sickle Cell Disease. Blood. 2019;134 (Suppl 1):790. https://doi.org/10.1182/blood-2019-126589 